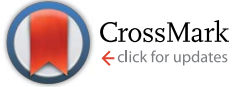

Cite this: RSC Adv., 2017, 7, 8376

Received 26th November 2016 Accepted 12th January 2017

DOI: $10.1039 / c 6 r a 27385 h$

www.rsc.org/advances

\section{Biological degradation of potato pulp waste and microbial community structure in microbial fuel cells}

\begin{abstract}
Yushi Tian, ${ }^{a}$ Xiaoxue Mei, ${ }^{a}$ Qing Liang, ${ }^{a}$ Di Wu, ${ }^{\text {ab }}$ Nanqi Ren ${ }^{a}$ and Defeng Xing ${ }^{\star a}$
The microbial electrochemical cell (MEC) is a promising waste treatment technology to accomplish simultaneous alternative energy production and degradation of organic matters. Potato pulp waste (PPW) from a potato processing plant contains a large amount of carbohydrates that need be degradated before discharge into the environment. Here, we describe electricity generation in singlechamber microbial fuel cells (MFCs) using PPW. Different organic loadings of PPW influenced obviously the power output of MFCs. The maximum power density of $32.1 \pm 0.5 \mathrm{~W} \mathrm{~m}^{-3}$ was obtained in a MFC fed with $10 \mathrm{~g} \mathrm{~L}^{-1}$ PPW. Microbial community analysis based on high-throughput sequencing of $16 \mathrm{~S}$ rRNA gene indicated that the predominant populations were obviously different in the MFCs. The syntrophic interactions between polysaccharide-degrading bacteria and exoelectrogens in the anode biofilms drove the cascade utilization of potato pulp waste in MFCs.
\end{abstract}

\section{Introduction}

As the largest potato producing country in the world, China produces more than 20 percent of the global yield. One-seventh of all the potatoes in China are consumed for the production of starch and starch-based products. ${ }^{1}$ The extensive waste residues and wastewater produced by potato starch processing plants cause serious environmental problems. ${ }^{2}$ The potato pulp is one of the by-products during potato starch production and their utilization is important for the starch industry. ${ }^{3}$ The potato pulp waste contains a high ratio of starch, cellulose, hemicellulose and pectin but has low protein. ${ }^{4}$ The traditional treatment technologies of potato pulp waste include landfill, incineration and animal feed, which are no longer preferred due to secondary pollution and energy recovery considerations. ${ }^{5,6}$

In recent years, the recovery of organic resources and energy from potato waste, such as potato pulp and peel, have been intensively investigated. Bioenergy (bioethanol and methane) and bioresource (lactic acid, single cell protein) could be generated using the potato waste through microbial fermentation or anaerobic digestion. ${ }^{7-10}$ However, the high energy consumption is a major challenge for the cost reductions of the bioresource and bioenergy production processes. ${ }^{11}$ Therefore, an environmentally friendly technology should be developed for the disposal and energy recovery of the potato waste.

${ }^{a}$ State Key Laboratory of Urban Water Resource and Environment, Harbin Institute of Technology, Harbin 150090, P. R. China. E-mail: dxing@hit.edu.cn; Fax: +86 451 86289195; Tel: +8645186289195

${ }^{b}$ College of Life Science, Northeast Forestry University, Harbin 150040, China
Microbial fuel cell (MFC) is a sustainable waste treatment technology emerging in recent years, ${ }^{12-15}$ which can convert chemical energy into electricity using the organic matters such as carbohydrates, cellulose and protein. ${ }^{16,17}$ The exoelectrogenic bacteria attached on the anode surface of MFCs serves as the biocatalysts to oxidize the substrates and transfer extracellular electrons to the electrode. ${ }^{18,19}$ In the previous studies on MFCs, glucose, acetate and sucrose or domestic and industry wastewater were most commonly used as the substrate..$^{20-24}$ Moreover, MFCs have been used in the bioenergy recovery from the solid waste such as cellulose biomass and waste sludge. ${ }^{25-31}$ Solid waste disposal using MFCs is not common as MFC based wastewater treatment and it is not well studied. The performances of MFC with given configuration depend on the microbial community structure on the electrodes. Multiple syntrophic interactions drive the degradation of complex organics matters and bioenergy generation in microbial electrochemical cells. ${ }^{32-34}$ In this study, the effect of organic loading on the performances of single-chamber microbial fuel cells fed with potato pulp waste was investigated. To probe the microbial interaction in the MFCs fed with potato pulps waste, microbial community structure of the anode biofilms was analyzed using 454 pyrosequencing of $16 \mathrm{~S}$ rRNA gene amplicons.

\section{Materials and methods}

\section{Potato pulps waste}

Potato pulps waste (PPW) was obtained from a potato starch processing plant (Harbin, China). Prior to use, PPW was generally crushed using an electrical blender (starch factory) and stored in a refrigerator $\left(4^{\circ} \mathrm{C}\right)$. The chemical oxygen demand 
(COD) and $\mathrm{pH}$ of pretreated potato pulps were $2000-25000 \mathrm{mg}$ $\mathrm{L}^{-1}$ and 4.0-4.9, respectively. The PPW was diluted to $1,5,10$ and $20 \mathrm{~g} \mathrm{~L}^{-1}$ with $50 \mathrm{mM}$ phosphate buffer solution (PBS) contained (per liter) $4.58 \mathrm{~g} \mathrm{Na} \mathrm{HPO}_{4}, 2.45 \mathrm{~g} \mathrm{NaH}_{2} \mathrm{PO}_{4}, 0.31 \mathrm{~g}$ $\mathrm{NH}_{4} \mathrm{Cl}$ and $0.13 \mathrm{~g}$ KCl. ${ }^{35}$ Finally, $\mathrm{pH}$ of diluted PPW was neutralized to around 7.0 prior to feeding.

\section{MFC configuration and operation}

Single-chamber MFCs with liquid volume of $25 \mathrm{~mL}$ were used as previously described. ${ }^{14}$ The anode was made by using graphite brush with length of $3 \mathrm{~cm}$ and outer diameter of $3 \mathrm{~cm} .{ }^{36}$ Carbon cloth (30\% wet proofed, E-Tek) air cathodes with a $0.5 \mathrm{mg} \mathrm{cm}^{-2}$ $\mathrm{Pt} / \mathrm{C}$ catalyst layer were fabricated as previously reported and the cathode was carbon cloth containing a $0.5 \mathrm{mg} \mathrm{cm} \mathrm{ct}^{-2} \mathrm{Pt}$ catalyst (30\% wet proofed, E-Tek). ${ }^{37}$ The MFCs were operated in fedbatch mode at $25{ }^{\circ} \mathrm{C}$ in duplicate for each test.

\section{Chemical analyses and calculations}

The chemical oxygen demand (COD) of the samples were measured according to standard method..$^{38}$ The estimated COD of the potato pulp waste was calculated based on the assumption that the potato pulp waste was only composed of starch with a molecular formula of $\left(\mathrm{C}_{6} \mathrm{H}_{10} \mathrm{O}_{5}\right)_{n}$ (molecular weight: $162 \mathrm{~g} \mathrm{~mol}^{-1}$ ). According to the assumption, the COD corresponded to $162 \mathrm{~g}$ (dry weight) potato pulp was $192 \mathrm{~g}$, which means that the ratio $\mathrm{COD} /$ potato-weight equals to 1.185.

The voltage (V) over a high-precision resistor of $1000 \Omega$ in the external circuit was measured at $30 \mathrm{~min}$ intervals using a multimeter data acquisition system (Model 2700, Keithly Instruments Inc, USA). Polarization curves were obtained by verifying external resistances from 2000 to $50 \Omega$. Power density, current density and coulombic efficiency (CE) were calculated as previously described..$^{14}$

\section{DNA extraction, PCR amplification and 454 pyrosequencing}

The anode biofilm samples for 454 GS FLX pyrosequencing analysis were obtained from the graphite fiber brush anodes of MFCs with satisfying performance after operated for two months. The graphite fiber brush was collected from respectively top, middle and bottom sections. Prior to DNA extraction, the samples were rinsed with sterile deionized water to remove the residual potato pulps. ${ }^{39}$ Genomic DNA was extracted using a PowerSoil DNA Isolation Kit (Mo Bio Laboratories, Carlsbad, $\mathrm{CA}$ ). The V1-V3 region ( $455 \mathrm{bp}$ ) of the bacterial 16S rRNA gene was amplified using a pair of bacterial universal primers as follows: 8F (5'-AGAGTTTGATCCTGGCTCAG-3') and 533R (5'TTACCGCGGCTGCTGGCAC- $3^{\prime}$ ). Individual samples were barcoded for pooling multiple samples in each run of sequencing of PCR amplicon of 16S rRNA gene using 454 GS-FLX System (Roche).

The sequencing reads were analyzed using Quantitative Insights into Microbial Ecology (QIIME) software (http:// qiime.org). Operational taxonomic units (OTUs) were determined using a 0.03 distance limit ( $97 \%$ similarity). A representative sequence from each OTU was selected for taxonomic identification using the Silva database (http://www.arb-silva.de) and Ribosomal Database Project (RDP) classifier (http:// rdp.cme.msu.edu). Principal component analysis (PCA) was conducted to visualize difference in community structure between different anode biofilms.

\section{Results and discussion}

Effect of PPW loading on electricity generation of MFCs

All MFCs fed with potato pulp waste immediately generated current after one week acclimation. The power densities of MFCs were measured after 30 days. The different organic loads of PPW obviously influenced the power output of MFCs. The power densities of MFCs improved with the increase of the organic load of PPW except $20 \mathrm{~g} \mathrm{~L}^{-1}\left(28.7 \pm 0.3 \mathrm{~W} \mathrm{~m}^{-3}\right)$ (Fig. 1). The maximum power density of $32.1 \pm 0.5 \mathrm{~W} \mathrm{~m}^{-3}$ was obtained in MFC fed with $10 \mathrm{~g} \mathrm{~L}^{-1} \mathrm{PPW}$, versus $26.4 \pm 0.2 \mathrm{~W} \mathrm{~m}^{-3}$ for MFCs fed with $5 \mathrm{~g} \mathrm{~L}^{-1} \mathrm{PPW}$ and $20.4 \pm 0.3 \mathrm{~W} \mathrm{~m}^{-3}$ for MFCs fed

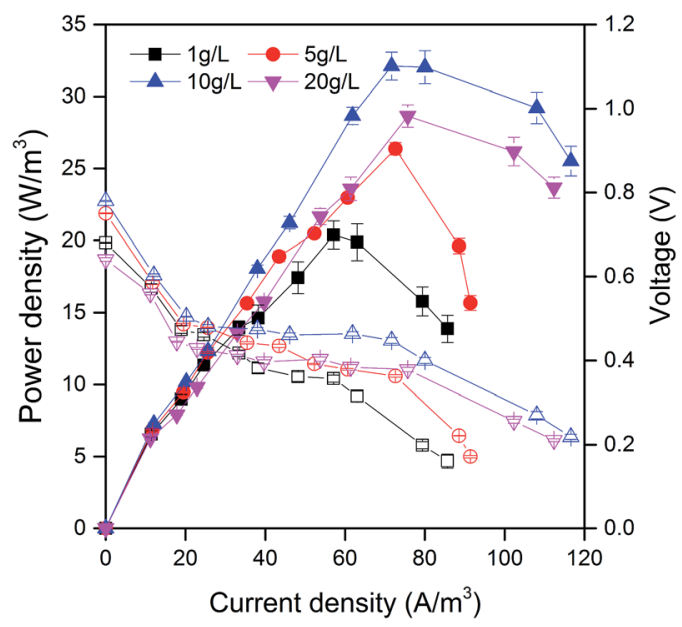

Fig. 1 Power density and polarization curves of MFCs fed with potato pulps waste of different organic loading rates. Error bars represent standard deviation based on measurements from duplicate reactors in at least three cycles.

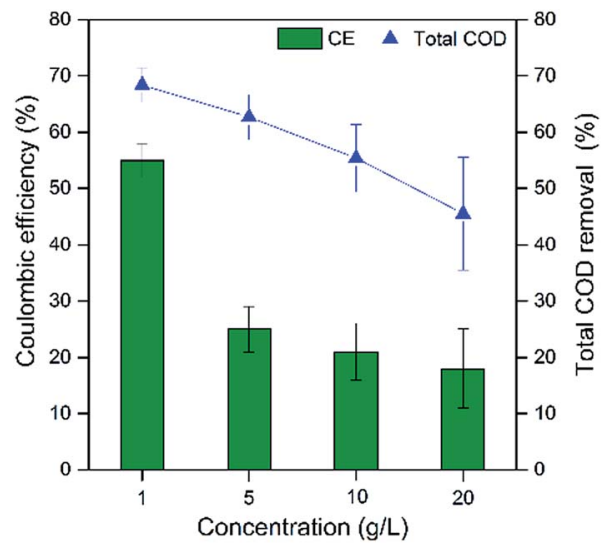

Fig. 2 Coulomb efficiency and total chemical oxygen demand (TCOD) removal of MFCs fed with potato pulps waste of different organic loading rates. 
with $1 \mathrm{~g} \mathrm{~L}^{-1}$ PPW. The optimal organic loading of PPW may result in the accessibility of the soluble organic substances for exoelectrogens of the anode biofilm. The maximum power density of MFCs fed with PPW was higher than that obtained from MFCs with starch processing wastewater $\left(9.6 \mathrm{~W} \mathrm{~m}^{-3}\right){ }^{40}$ which was also acceptable compared with previous reports on MFCs using food waste, beer brewery wastewater and corn stover. ${ }^{14,41,42}$

\section{Potato waste residue treatment efficiency}

The removal of total chemical oxygen demand (TCOD) in MFCs decreased with the increase of potato pulps organic loading (Fig. 2). The maximum TCOD removal of $68.4 \%$ was obtained in MFCs fed with $1 \mathrm{~g} \mathrm{~L}^{-1} \mathrm{PPW}$, with $62.7 \%$ of MFCs fed with $5 \mathrm{~g} \mathrm{~L}^{-1}$ PPW and 55.4\% of MFCs fed with $10 \mathrm{~g} \mathrm{~L}^{-1}$ and $20 \mathrm{~g} \mathrm{~L}^{-1}$ PPW. A maximum total suspended solids (TSS) removal of $56.8 \%$ was obtained in MFCs fed with $20 \mathrm{~g} \mathrm{~L}^{-1}$ PPW, with 53.6\% of MFCs fed with $10 \mathrm{~g} \mathrm{~L}^{-1}$. MFCs fed with $1 \mathrm{~g} \mathrm{~L}^{-1}$ and $5 \mathrm{~g} \mathrm{~L}^{-1} \mathrm{PPW}$ obtained slightly lower solid removal of $50.6 \%$ and $50.4 \%$, respectively ( $5 \mathrm{~g} \mathrm{~L}^{-1}$ ) (Fig. 3). The coulombic efficiencies (CEs) of the MFCs fed with PPW were 18-56\%. TSS removal of 50.4$56.8 \%$ indicated that the residues of starch, cellulose and hemicellulose occurred in the effluent, suggesting to enhance the hydrolysis is important to improve PPW degradation. ${ }^{29-31,43}$

\section{Microbial community structure in the anode biofilms of MFCs}

Total 4419, 2672, 4096 and 4710 high-quality reads were obtained from the anode biofilms of MFCs fed with PPW of $1 \mathrm{~g}$ $\mathrm{L}^{-1}, 5 \mathrm{~g} \mathrm{~L}^{-1}, 10 \mathrm{~g} \mathrm{~L}^{-1}$ and $20 \mathrm{~g} \mathrm{~L}^{-1}$, respectively, which corresponded to the operational taxonomic units (OTUs) of 640, 525, 624 and 812. The Shannon index of MFCs fed with $5 \mathrm{~g} \mathrm{~L}^{-1} \mathrm{PPW}$ was highest 5.11 and lowest was 4.39 for MFC fed with $10 \mathrm{~g} \mathrm{~L}^{-1}$ PPW. The diversity indices of MFCs fed with $1 \mathrm{~g} \mathrm{~L}^{-1} \mathrm{PPW}$ and $20 \mathrm{~g} \mathrm{~L}^{-1}$ PPW were similar (4.74 and 4.63). The three predominant phyla in all MFCs were Bacteroidetes, Proteobacteria and

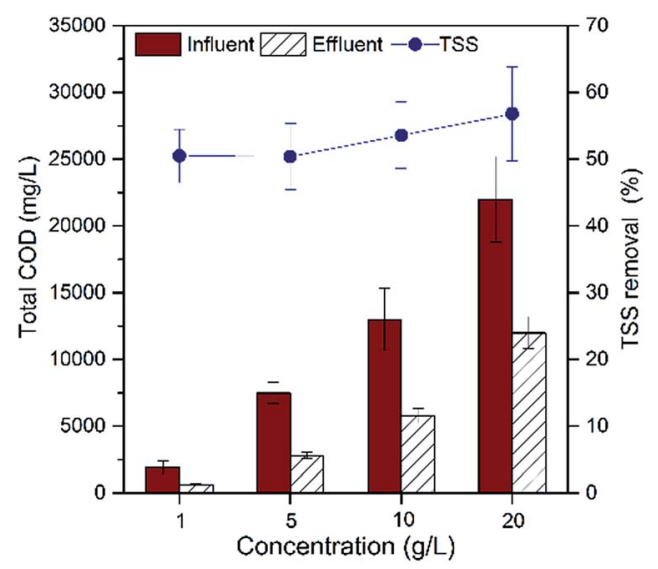

Fig. 3 Removal efficiency of total chemical oxygen demand (TCOD) and total solid suspended (TSS) removal of rMFCs fed with potato pulps waste of different organic loading rates. Error bars represent maximum deviation based on measurements from duplicate reactors in at least one month.
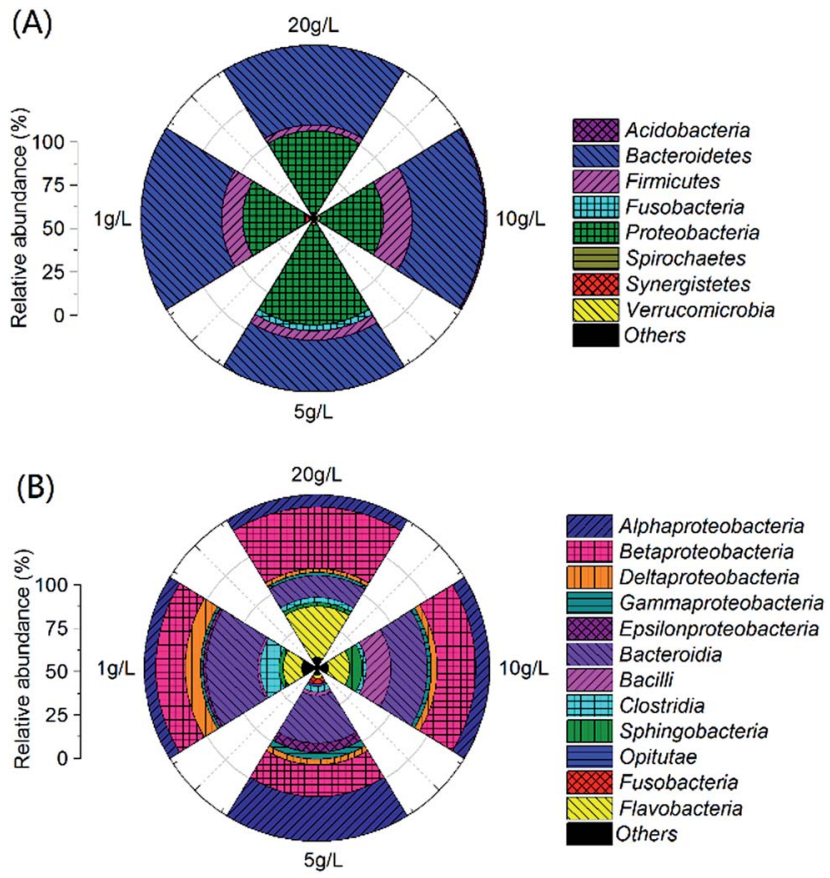

Fig. 4 Taxonomic classification of $16 \mathrm{~S}$ rRNA gene amplicons for 454 pyrosequencing at the (A) phyla and (B) class. Relative abundance was defined as the number of sequences affiliated with that class or genus divided by the total number of sequences per sample. Phyla and classes making up less than $1 \%$ of total composition in all three libraries were classified as "others".

Firmicutes (Fig. 4A). The relative abundance of Firmicutes in MFCs fed with $10 \mathrm{~g} \mathrm{~L}^{-1}$ PPW accounted for $12.2 \%$, which might facilitate hydrolysis of PPW and provide the electron donors for exoelectrogens. ${ }^{39}$ The predominate classes belonged to Alphaproteobacteria, Bacteroidia, Bacilli, Betaproteobacteria, Flavobacteria and Clostridia (Fig. 4B). The relative abundance of Clostridia (10.8\%) in the MFCs fed with $10 \mathrm{~g} \mathrm{~L}^{-1}$ PPW were higher than that in the other MFCs (2.2-3.4\%).

The majority of predominant populations were affiliated with Bacteroides, Flavobacterium, Geobacter and Dysgonomonas (Fig. 5). The relative abundance of Bacteroides was 7.1\% $\left(20 \mathrm{~g} \mathrm{~L}^{-1}\right), 9.5 \%$ $\left(1 \mathrm{~g} \mathrm{~L}^{-1}\right)$ and $10.6 \%\left(5 \mathrm{~g} \mathrm{~L}^{-1}\right)$, respectively. Flavobacterium showed the most dominant portion in $20 \mathrm{~g} \mathrm{~L}^{-1}(21.4 \%)$, followed by $1 \mathrm{~g}$ $\mathrm{L}^{-1}(12.1 \%), 10 \mathrm{~g} \mathrm{~L}^{-1}(8.4 \%)$ and $5 \mathrm{~g} \mathrm{~L}^{-1}$ (1.9\%). Bacteroides and Flavobacterium were reported to be related to starch degradation. ${ }^{4,45}$ Ruminococcus capable of cellulose-degradation, took up $6.8 \%$ in MFCs fed with $10 \mathrm{~g} \mathrm{~L}^{-1} \mathrm{PPW},{ }^{46}$ implying that both starch and cellulose were degraded and utilized, which led to an easilier taken substrates background for exoelectrogens and end up with better electricity production. Open-circuit MFCs also showed TSS removal, implying that both planktonic bacteria and biofilms on the electrodes contributed to the degradation of starch and cellulose or TSS removal of PPW. There are difference in the predominate populations between planktonic bacteria and anode biofilms in MFCs. ${ }^{32}$ To enhance the hydrolysis of starch and cellulose, optimization of biofilm populations and planktonic community in MFCs need be further investigated in the future study. 


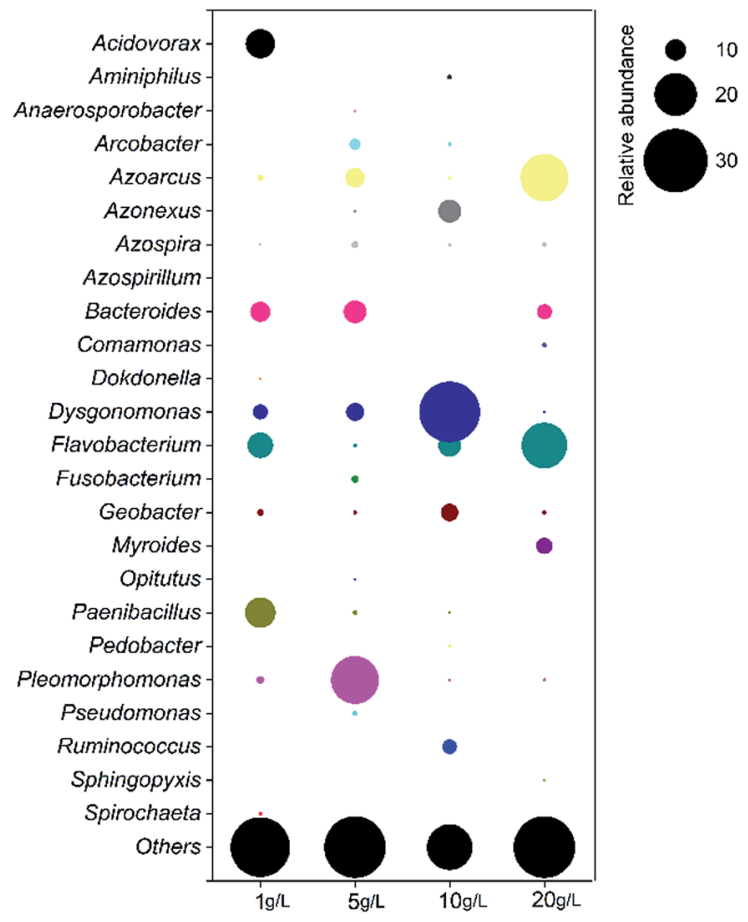

Fig. 5 The relative abundance of predominant genera in microbial communities of MFC fed with PPW of different concentrations. "Others" represents genera which relative abundance are less than $1 \%$ of total composition

The predominant exoelectrogens in MFCs were affiliated with Geobacter and Dysgonomonas. Both of them took up the highest portion in MFCs fed with $10 \mathrm{~g} \mathrm{~L}^{-1} \mathrm{PPW}$, which was $8.2 \%$ (Geobacter) and 28.5\% (Dysgonomonas). The percentage Geobacter represented among the other three organic loading groups were $3.1 \%\left(1 \mathrm{~g} \mathrm{~L}^{-1}\right), 1.8 \%\left(5 \mathrm{~g} \mathrm{~L}^{-1}\right)$ and $2.2 \%\left(20 \mathrm{~g} \mathrm{~L}^{-1}\right)$, while that of Dysgonomonas were $7.1 \%\left(1 \mathrm{~g} \mathrm{~L}^{-1}\right), 8.4 \%\left(5 \mathrm{~g} \mathrm{~L}^{-1}\right)$ and $1.6 \%\left(20 \mathrm{~g} \mathrm{~L}^{-1}\right)$. Dysgonomonas sp. was proved to be related to electricity generation in previous researches. ${ }^{47-49}$ Previous investigations on the degradation of cellulose, semicellulose and starch using MFC were focused on electricity generation, few studies monitored the community structures using conventional technology denaturing gradient gel electrophoresis (DGGE) of $16 \mathrm{~S}$ rRNA gene. ${ }^{24}$ Community analyses based on 454 pyrosequencing shows that diverse the cellulose- or starchdegrading bacteria and exoelectrogens (Geobacter and Dysgonomonas) are present in the anode biofilms, hence, to get insight into the syntrophic interaction between these populations is important to recover bioenergy from PPW in microbial electrochemical cells.

\section{Conclusions}

Simultaneous degradation of the potato pulps waste (PPW) and electricity generation were implemented using microbial fuel cells. The organic loading of PPW influenced obviously the performances of MFCs, the maximum power density of $32.1 \mathrm{~W}$ $\mathrm{m}^{-3}$ was obtained in MFCs fed with $10 \mathrm{~g} \mathrm{~L}^{-1}$ PPW. The 454 pyrosequencing of 16S rRNA gene amplicons indicated that the difference in the microbial community occurred between the anode biofilms of MFCs fed with different organic loading of PPW. The predominant populations in the anode biofilms were affiliated with exoelectrogenic Geobacter and Dysgonomonas, and polysaccharide-degrading bacteria. The syntrophic interaction between exoelectrogenic and fermentative bacteria drove the electricity generation and degradation of PPW. MFCs provides another approach for potato pulps waste treatment and bioenergy generation.

\section{Acknowledgements}

This study was supported by National Natural Science Foundation of China (No. 51422805 and 31270004 ), the Science Fund for Distinguished Young Scholars of Heilongjiang Province (Grant No. JC201407), the State Key Laboratory of Urban Water Resource and Environment (Harbin Institute of Technology) (No. 2016DX10), the Fundamental Research Funds for the Central Universities (No. HIT.BRETIII. 201232).

\section{References}

1 D. Wu, Procedia Environ. Sci., 2016, 31, 108-112.

2 B. Liu, Y. Li, J. Song, L. Zhang, J. Dong and Q. Yang, Cellulose, 2014, 21, 3637-3645.

3 U. Klingspohn and K. Schügerl, J. Biotechnol., 1993, 29, 109119.

4 F. Mayer, Polym. Degrad. Stab., 1998, 59, 231-235.

5 M. Nelson, J. Anim. Sci., 2010, 88, E133-E142.

6 K. Saito, T. Noda, S. Tsuda, M. Mori, Y. Hasa, H. Kito and Y. Oda, Bioresour. Technol., 2006, 97, 2470-2473.

7 E. Cibis, M. Krzywonos and T. Miśkiewicz, Bioresour. Technol., 2006, 97, 679-685.

8 V. Kryvoruchko, A. Machmüller, V. Bodiroza, B. Amon and T. Amon, Biomass Bioenergy, 2009, 33, 620-627.

9 S. Liang and A. G. McDonald, Waste Management, 2015, 46, 197-200.

$10 \mathrm{H}$. Zhu, A. Stadnyk, M. Béland and P. Seto, Bioresour. Technol., 2008, 99, 5078-5084.

11 F. Bai, W. Anderson and M. Moo-Young, Biotechnol. Adv., 2008, 26, 89-105.

12 Y. Feng, W. He, J. Liu, X. Wang, Y. Qu and N. Ren, Bioresour. Technol., 2014, 156, 132-138.

13 W. He, W. Yang, Y. Tian, X. Zhu, J. Liu, Y. Feng and B. E. Logan, J. Power Sources, 2016, 332, 447-453.

14 J. Jia, Y. Tang, B. Liu, D. Wu, N. Ren and D. Xing, Bioresour. Technol., 2013, 144, 94-99.

15 S. Srikanth and S. V. Mohan, Bioresour. Technol., 2012, 119, 241-251.

16 D. Pant, G. Van Bogaert, L. Diels and K. Vanbroekhoven, Bioresour. Technol., 2010, 101, 1533-1543.

17 K. Rabaey and W. Verstraete, Trends Biotechnol., 2005, 23, 291-298.

18 D. R. Bond and D. R. Lovley, Appl. Environ. Microbiol., 2003, 69, 1548-1555.

19 G. T. R. Palmore and H.-H. Kim, J. Electroanal. Chem., 1999, 464, 110-117. 
20 B. Min and B. E. Logan, Environ. Sci. Technol., 2004, 38, 5809-5814.

21 B. Min, J. Kim, S. Oh, J. M. Regan and B. E. Logan, Water Res., 2005, 39, 4961-4968.

22 X. Wang, Y. Feng and H. Lee, Water Sci. Technol., 2008, 57, 1117-1122.

23 S. A. Patil, V. P. Surakasi, S. Koul, S. Ijmulwar, A. Vivek, Y. Shouche and B. Kapadnis, Bioresour. Technol., 2009, 100, 5132-5139.

24 N. J. Beecroft, F. Zhao, J. R. Varcoe, R. C. T. Slade, A. E. Thumser and C. Avignone-Rossa, Appl. Microbiol. Biotechnol., 2012, 93, 423-437.

25 X. Wang, Y. Feng, H. Wang, Y. Qu, Y. Yu, N. Ren, N. Li, E. Wang, H. Lee and B. E. Logan, Environ. Sci. Technol., 2009, 43, 6088-6093.

26 Y. Zhang, B. Min, L. Huang and I. Angelidaki, Appl. Environ. Microbiol., 2009, 75, 3389-3395.

27 G. Zhang, Q. Zhao, Y. Jiao, K. Wang, D. Lee and N. Ren, Biosens. Bioelectron., 2012, 31, 537-543.

28 L. Lu, D. Xing, B. Liu and N. Ren, Water Res., 2012, 46, 10151026.

29 F. Rezaei, T. L. Richard and B. E. Logan, Biotechnol. Bioeng., 2008, 101, 1163-1169.

30 J. Niessen, U. Schröder and F. Scholz, Electrochem. Commun., 2004, 6, 955-958.

31 Z. Ren, T. E. Ward and J. M. Regan, Environ. Sci. Technol., 2007, 41, 4781-4786.

32 Z. Wang, Y. Zheng, Y. Xiao, S. Wu, Y. Wu, Z. Yang and F. Zhao, Bioresour. Technol., 2013, 144, 74-79.

33 L. Lu, D. Xing, N. Ren and B. E. Logan, Bioresour. Technol., 2012, 124, 68-76.
34 Q. Liu, Z. J. Ren, C. Huang, B. Liu, N. Ren and D. Xing, Biotechnol. Biofuels, 2016, 9, 162.

35 H. Liu and B. E. Logan, Environ. Sci. Technol., 2004, 38, 40404046.

36 B. E. Logan, S. Cheng, V. Watson and G. Estadt, Environ. Sci. Technol., 2007, 41, 3341-3346.

37 S. Cheng, H. Liu and B. E. Logan, Electrochem. Commun., 2006, 8, 489-494.

38 E. W. Rice, R. B. Baird, A. D. Eaton and L. S. Clesceri, Standard methods for the examination of water and wastewater, Washington, DC, 22nd edn, 2012.

39 L. Lu, D. Xing and N. Ren, Water Res., 2012, 46, 2425-2434.

40 N. Lu, S. Zhou, L. Zhuang, J. Zhang and J. Ni, Biochem. Eng. J., 2009, 43, 246-251.

41 Y. Zuo, P. C. Maness and B. E. Logan, Energy Fuels, 2006, 20, 1716-1721.

42 Y. Feng, X. Wang, B. E. Logan and H. Lee, Appl. Environ. Microbiol., 2008, 78, 873-880.

43 L. R. Lynd, P. J. Weimer, W. H. van Zyl and I. S. Pretorius, Microbiol. Mol. Biol. Rev., 2002, 66, 506-577.

44 D. Van der Kooij and W. A. Hijnen, Appl. Environ. Microbiol., 1981, 41, 216-221.

45 K. L. Anderson and A. A. Salyers, J. Bacteriol., 1989, 171, 3192-3198.

46 P. Weimer, A. Conner and L. Lorenz, Appl. Environ. Microbiol., 2003, 63, 29-34.

47 B. E. Logan and J. M. Regan, Trends Microbiol., 2006, 14, 512518.

48 Y. Kodama, T. Shimoyama and K. Watanabe, Int. J. Syst. Evol. Microbiol., 2012, 62, 3055-3059.

49 R. Liu, C. Gao, Y. Zhao, A. Wang, S. Lu, M. Wang, F. Maqbool and Q. Huang, Bioresour. Technol., 2012, 123, 86-91. 